\section{Evaluation of Peginterferon alfa-2a Response Rate in HBe-Negative Chronic Hepatitis B: A Systematic Review and Meta-Analysis}

\author{
Jia Shi \\ Medical College, Weinan Vocational and Technical College, Weinan, 714000, China
}

\begin{abstract}
A B S T R A C T
Selecting the best medications for ALT and HBV-DNA control in HBeAg negative chronic hepatitis patients is necessary as they are vulnerable to developing cirrhosis and hepatocellular carcinoma. The present study was aimed to evaluate the response rate of treatment by Peginterferon alfa- $2 \mathrm{a}$. In this systematic review and meta-analysis, a review of articles evaluating response rate to Peginterferon alfa2a was done through the databases of Scopus, Google Scholar, Pubmed (inception - 2019). Fourteen studies reporting the response rate of $\mathrm{HBeAg}$ negative chronic patients' response to Peginterferon alfa2a were included in the study. Cochran test was used to determine the homogeneity of the samples (based on $\mathrm{Q}$ test and $\mathrm{I}^{2}$ index). The prevalence was estimated based on the Random Effect size model in Revman software (version 3.5). The main result of this study showed that, in the 14 studies that PEG interferon was prescribed for patients with $\mathrm{Hbe} \mathrm{Ag}$ negative chronic hepatitis $\mathrm{B}$, the pooled incidence of treatment responders in comparison to non-responders was significantly lower $(\mathrm{OR}=0.78, \mathrm{CI}(0.7-0.87)$, $\mathrm{p}<0.0001)$. High heterogeneity was observed in this analysis $\left(\mathrm{I}^{2}=95 \%, \mathrm{p}<0.0001\right)$. to investigate factors affecting heterogeneity, a subgroup analysis was done based on the HBV genotype. 5 Studies in which most patients (>90\%) had C genotype were compared with 3 studies with D genotype dominant study population. Again a high heterogeneity was observed in both genotype $\mathrm{C}$ and $\mathrm{D}$ dominant $\left(\mathrm{I}^{2}=92 \%\right.$ and $95 \%$, respectively). However, higher pooled responders to non-responders rate were seen in C dominant populations versus $\mathrm{D}$ genotype $(\mathrm{OR}=0.72, \mathrm{CI}(0.69-0.75), \mathrm{p}<0.0001)$. Using Peginterferon alfa-2a alone is not the best choice of treatment due to the low rate of response to treatment; while considering the patient's HBV genotype is important in response rate.
\end{abstract}

\section{INTRODUCTION}

$\mathrm{H}$ epatitis B is one of viral hepatitis that has more than 300 million carriers worldwide and about one million people die each year due to its complications. Hepatitis B virus is one of the causes of acute and chronic hepatitis, liver cirrhosis and hepatocellular carcinoma (Asrani et al., 2019). Clinically important viral proteins concerning hepatitis B disease course include HBsAg, $\mathrm{HBcAg}$, $\mathrm{HBeAg}$, which HBsAg indicates infection with hepatitis $\mathrm{B}$ and its anti-HBs antibodies indicate improvement and immunity against the disease (Cherre et al., 2019). Clinical signs and symptoms of this infection vary, resulting in acute, chronic, no-clinical symptoms, and even fulminant infections. Acute infection is somewhat self-limited and is associated with inflammation and necrosis of the liver cells. The mortality rate in acute infection is about 0.5 to $1 \%$ (Malani, 2010). HbsAg in the blood or serum for more than six months indicates chronic infection. Upon HBV entry into the body, the disease gets chronic in $95 \%$ of

\footnotetext{
Corresponding author: jiashi.academic@yahoo.com 0030-9923/2021/0003-0835 \$ 9.00/0

Copyright 2021 Zoological Society of Pakistan
}

children and 3 to 5\% of adults (Nicolini et al., 2019).

Initial evaluation of a person with chronic $\mathrm{HBV}$ infection requires measurement of $\mathrm{HBeAg}$ and $\mathrm{HBeAb}$ levels and serum HBV DNA levels (Wilkins et al., 2019). Newborns born of mothers with chronic hepatitis often have $\mathrm{HBe} \mathrm{Ag}$ virus, HBV positive, normal enzymes, high virus titers and mild disease in the biopsy. This is called the immune tolerant phase (Lee, 1997). This stage may last for the second and third decades of life. After this stage, liver enzymes are elevated in some patients, while still positive for $\mathrm{HBe} \mathrm{Ag}$ and most liver biopsies show significant and severe liver disease. This phase is called HBe Ag positive chronic hepatitis (Mahoney, 1999). Prolonged liver fibrosis or cirrhosis may develop if this stage gets prolonged. After this stage, spontaneously or with treatment, HBeAb seroconversion occurs as $\mathrm{HBe} A g$ becomes negative and $\mathrm{HBeAb}$ becomes positive. In the majority of patients, after a course of hepatic failure, hepatic enzymes become normal and the severity of liver disease decreases. These patients are called inactive HBV carriers (Fujisawa et al., 2000). These patients have a good prognosis and may live for decades and die due to reasons other than liver disease. However, some of these patients, with $\mathrm{HBeAg}$ negative, have high viral titers and elevated liver enzymes and 
show significant liver disease in liver biopsy. This group of patients is called $\mathrm{HBeAg}$ negative chronic hepatitis individuals. Such patients may experience cirrhosis and hepatocellular carcinoma. Most HBV-negative cirrhosis patients have $\mathrm{HBe} \mathrm{Ag}$ (Chu et al., 2002). Chronic hepatitis $\mathrm{B}$ is difficult to be treated as many patients require longterm treatment with expensive medications and the possibility of drug resistance, so treatment should only be initiated in patients who really need treatment and the best medical regimen should be prescribed for good treatment response (Raimondo and Pollicino, 2016).

In patients with $\mathrm{HBeAg}$-positive chronic hepatitis, the goal of treatment is to achieve HBeAg-negative status. In the treatment of patients with $\mathrm{HBeAg-negative} \mathrm{chronic}$ hepatitis, the goal is to normalize ALT and suppress the virus continuously, so that HBV DNA should get negative or negative less than $2000 \mathrm{IU} / \mathrm{ml}$ (Sundaram and Kowdley, 2015; Mohanty et al., 2006).

To date, seven drugs have been approved for the treatment of chronic hepatitis, including interferon-alpha, PEG interferon, lamivudine, adenovir adipovir dipivocal, entektavir, telbivodine teno firavir interferon (Yuen et al., 2011).

PEGylated recombinant human interferon-alpha 2A is an inducer of an innate antiviral immune response. One of the benefits of using PEG Interferon is the specific duration of treatment with this drug and the lack of drug resistance. The purpose of this research was to assess Peginterferon alfa-2a's response rate to therapy (Fung et al., 2016).

\section{METHODS}

This study is a meta-analysis of the ratio of response to treatment with PEG interferon-alpha in patients with $\mathrm{HBeAg-negative} \mathrm{chronic} \mathrm{hepatitis} \mathrm{in} \mathrm{comparison} \mathrm{of} \mathrm{non-}$ responding patients, in a variety of studies, using literature review and meta-analysis of existing sources between 1900 and 2019. Articles published in the Pub Med, ISI Web of Science, SCOPUS and Google scholar databases have been used to find relevant studies. The search strategy was mainly done using the systematic search with all possible combinations of the following keywords: Hbe Ag negative chronic hepatitis B, HBV, DNA, ALT, Peginterferon alfa-2a.

\section{Criteria for selection and evaluation of articles quality}

Initially, a list of the titles and abstracts of all the articles in the databases were provided by the researcher and independently reviewed to determine and select the relevant titles. Then the related articles were independently entered into the study process. The main criterion for the various articles in this study is: (i) studies reporting responder and non-responder patients in Hbe Ag negative chronic hepatitis B patients receiving PEG interferon, and (ii) unrelated studies to the treatment of HBeAg-negative chronic hepatitis with PEG interferon alpha have been excluded.

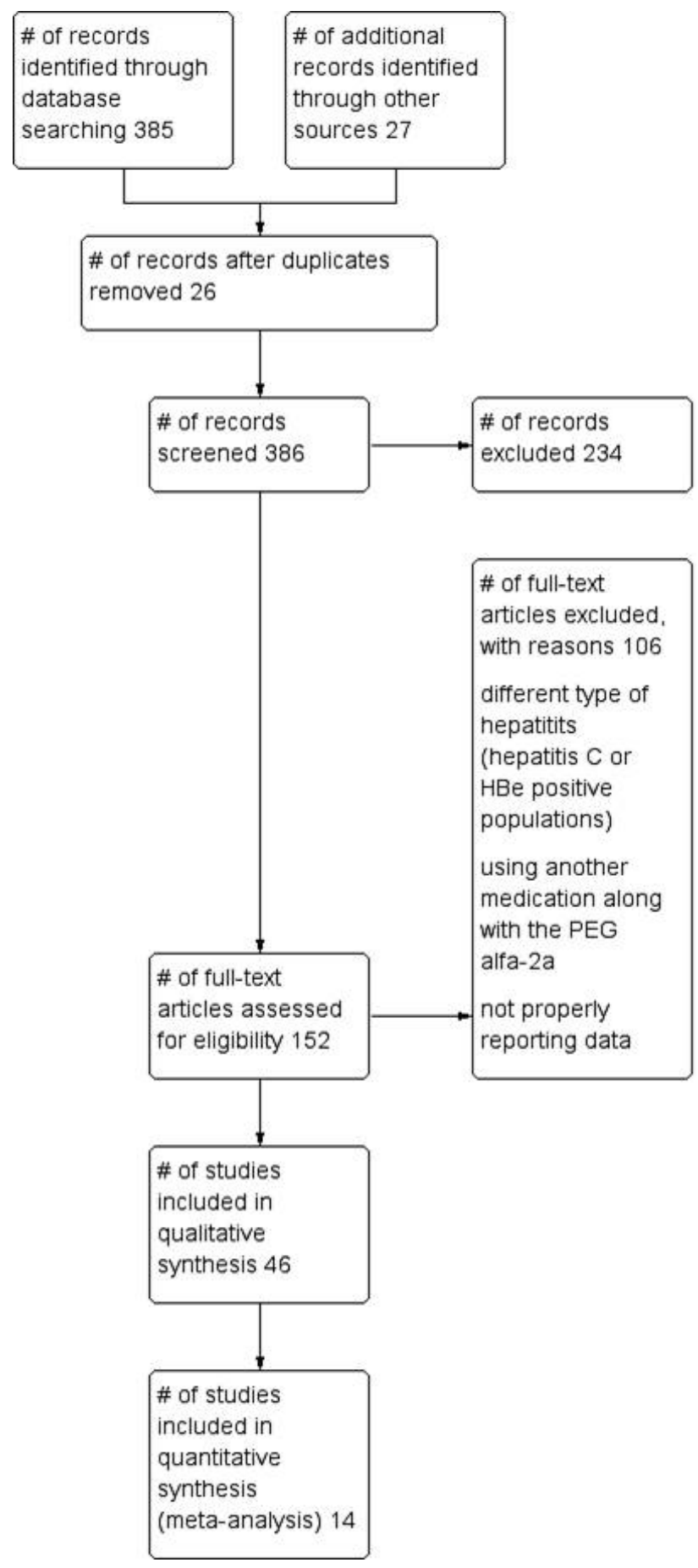

Fig. 1. Study flow. 
Secondly, after identifying relevant reviews in terms of titles, the abstract of the various papers selected by the researcher using the STROBE (The Strengthening the Reporting of Observational Studies in Epidemiology) checklist which is an internationally renowned standard and quality statement for studies' quality assessment. The checklist consists of 43 different sections and includes various aspects of the methodology including sampling methods, variables measurement, and statistical analysis, adjusting for confounders, mentioning the validity and reliability of the tools used and the objectives of the study. A minimum score of 40 was deemed necessary in this checklist for inclusion of study. There was no need to assess Publication Bias and Funnel Plot, depending on the use of the quality control checklist; however study bias was shown in Figure 1. Based on the explanations given in the first step, 386 articles were selected. After reviewing the titles, 152 articles were identified to be related to the topic and entered the next phase, and 98 articles were removed due to being not relevant to the research topic. Related articles were identified and entered the second phase of the qualitative evaluation of abstracts. At the end of this phase, 32 articles that did not report our desired factors were excluded from the study. Finally, 14 studies were included in statistical analysis and their information is presented in Table I. The flow diagram of study selection based on PRISMA is shown in Figure 1.

\section{Statistical analysis}

The ratio of the number of responders to nonresponders in each study was determined first. The ratio standard error the true proportion (SE) was calculated using the following formula:

$$
S E=\sqrt{[P \times(1-P)] / N}
$$

Where, $\mathrm{P}$ is proportion and $\mathrm{N}$ is the number of all subjects.

The weight of each study was calculated based on the Fix Effect Model (Hackshaw, 2009). Then, taking into account the weight of each study, the relative amounts obtained were combined to determine heterogeneity (Random Effect size model) and the overall proportion was calculated. Finally, the heterogeneity index with a heterogeneity test between studies was determined using Cochran Q tests. After confirming that studies are heterogeneous, the best estimate was calculated based on the Random Effect model. The subtotal analysis was performed based on the type of HBV genotype. All analyses were conducted using Review Manager Version 5.3 (Nordic Cochrane Centre, Copenhagen, Denmark). The studies bias is shown in Figure 2.

Table I.- Characteristics of the studies included in the meta-analysis study.

\begin{tabular}{|c|c|c|c|c|c|c|c|c|}
\hline \multirow[t]{2}{*}{ Reference } & \multirow[t]{2}{*}{ Design } & \multirow[t]{2}{*}{ Country } & \multirow[t]{2}{*}{$\begin{array}{c}\text { Sample } \\
\text { size }\end{array}$} & \multirow[t]{2}{*}{$\begin{array}{c}\text { Mean } \\
\text { age }\end{array}$} & \multicolumn{2}{|c|}{$\begin{array}{c}\text { Most frequently } \\
\text { observed HBV genotype }\end{array}$} & \multicolumn{2}{|c|}{$\begin{array}{l}\text { Male gender } \\
(\%)\end{array}$} \\
\hline & & & & & Responders & $\begin{array}{c}\text { Non- } \\
\text { responder }\end{array}$ & Responders & $\begin{array}{c}\text { Non- } \\
\text { responder }\end{array}$ \\
\hline Bonino et al. (2007) & Prospective & China & 518 & 39.9 & $\mathrm{C}$ & 83 & 82 & $\mathrm{D}$ \\
\hline Brook et al. (1989) & $\mathrm{RCT}$ & UK & 114 & 35.8 & NA & 88.7 & 100 & NA \\
\hline Buster et al. (2009) & Retrospective & Netherlands & 721 & 33.6 & $\mathrm{C}$ & 79.3 & 70.3 & $\mathrm{C}$ \\
\hline Chuaypen et al. (2018) & $\mathrm{RCT}$ & Thailand & 121 & 40.4 & $\mathrm{C}$ & 68.6 & 74.3 & $\mathrm{C}$ \\
\hline de Niet et al. (2016) & Prospective & Amsterdam & 28 & 42 & $\mathrm{D}$ & 86 & 57 & A \\
\hline Manesis and Hadziyannis (2001) & Retrospective & Greece & 200 & 48.4 & NA & 91 & 82 & NA \\
\hline Goulis et al. (2015) & Prospective & Greece & 95 & 42 & $\mathrm{D}$ & 70 & 82 & $\mathrm{D}$ \\
\hline Lampertico et al. (2003) & Cohort & Italy & 101 & 46 & $\mathrm{D}$ & 93 & 77 & $\mathrm{D}$ \\
\hline Moucari et al. (2009) & Not clear & France & 48 & 44 & A & 83 & 83 & $\mathrm{D}$ \\
\hline Rijckborst et al. (2010) & $\mathrm{RCT}$ & Poland & 107 & 42 & $\mathrm{D}$ & 73.5 & 66.7 & $\mathrm{D}$ \\
\hline Tamai et al. (2017) & Cohort & Japan & 23 & 47 & $\mathrm{C}$ & 54.5 & 83 & $\mathrm{C}$ \\
\hline Tangkijvanich et al. (2010) & Retrospective & Thailand & 30 & 37 & $\mathrm{C}$ & 80 & 70 & $\mathrm{C}$ \\
\hline Tatsukawa et al. (2018) & $\mathrm{RCT}$ & Japan & 21 & 53 & $\mathrm{C}$ & 69 & 100 & $\mathrm{C}$ \\
\hline Zhang et al. (2016) & Prospective & China & 46 & 34.7 & NA & 70.6 & 66.7 & NA \\
\hline
\end{tabular}




\section{RESULTS}

In this meta-analysis study, 14 articles with a sample size of 1655 were included. The highest sample size (721 cases) was reported in the study of Buster et al. (2009) and the lowest (23 cases) in the study of Tamai et al. (2017). The general characteristics and information of the selected studies are presented in Table I.

Based on Figure 3, in the 14 studies that PEG interferon was prescribed for patients with Hbe Ag negative chronic hepatitis $\mathrm{B}$, the pooled incidence of treatment responders in comparison to non-responders was significantly lower
$(\mathrm{OR}=0.78$, CI $(0.7-0.87), \mathrm{p}<0.0001)$. High heterogeneity was observed in this analysis $(\mathrm{I} 2=95 \%, \mathrm{p}<0.0001)$.

A subgroup analysis was done based on the $\mathrm{HBV}$ genotype. 5 studies in which most patients $(>90 \%)$ had $\mathrm{C}$ genotype were compared with 3 studies with D genotype dominant study population. Again a high heterogeneity was observed in both genotype $\mathrm{C}$ and $\mathrm{D}$ dominant ( $\mathrm{I} 2=92 \%$ and $95 \%$, respectively). However, higher pooled responders to non-responders rate was seen in $\mathrm{C}$ dominant populations versus D genotype $(45.2 \%$ vs. $54.8 \%$. overall $\mathrm{OR}=0.72, \mathrm{CI}$ (0.69-0.75), $\mathrm{p}<0.0001)$, as shown in Figure 4.

\section{Random sequence generation (selection bias)}

Allocation concealment (selection bias)

\section{Blinding of participants and personnel (performance bias)}

\section{Blinding of outcome assessment (detection bias)}

Incomplete outcome data (attrition bias)

Low risk of bias

Selective reporting (reporting bias)

Unclear risk of bias

Other bias

High risk of bias

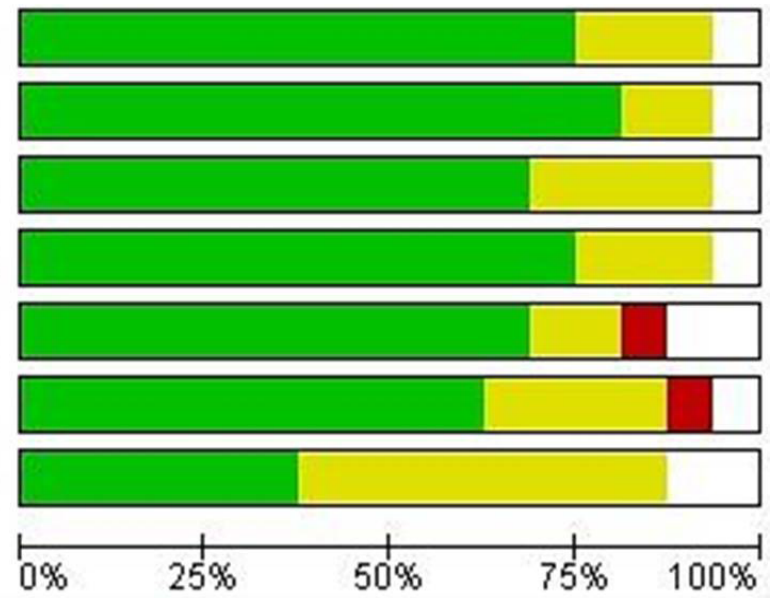

Fig. 2. Study bias summary.

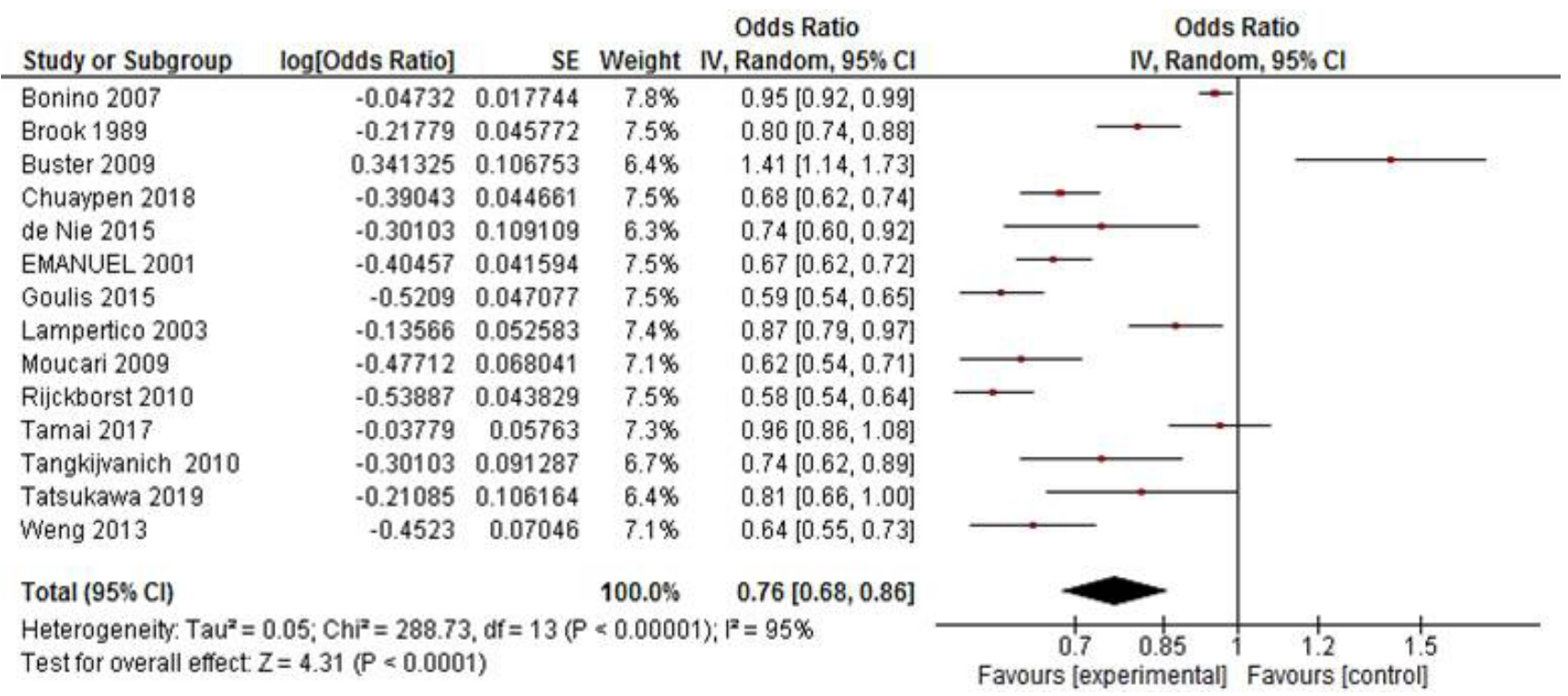

Fig. 3. Distribution of studies based on the ratio of the number of responders to non-responders. The $95 \%$ confidence interval for each study is plotted in horizontal lines around the baseline ratio. The rhombic mark is the result of a combination of studies with a $95 \%$ confidence interval. 


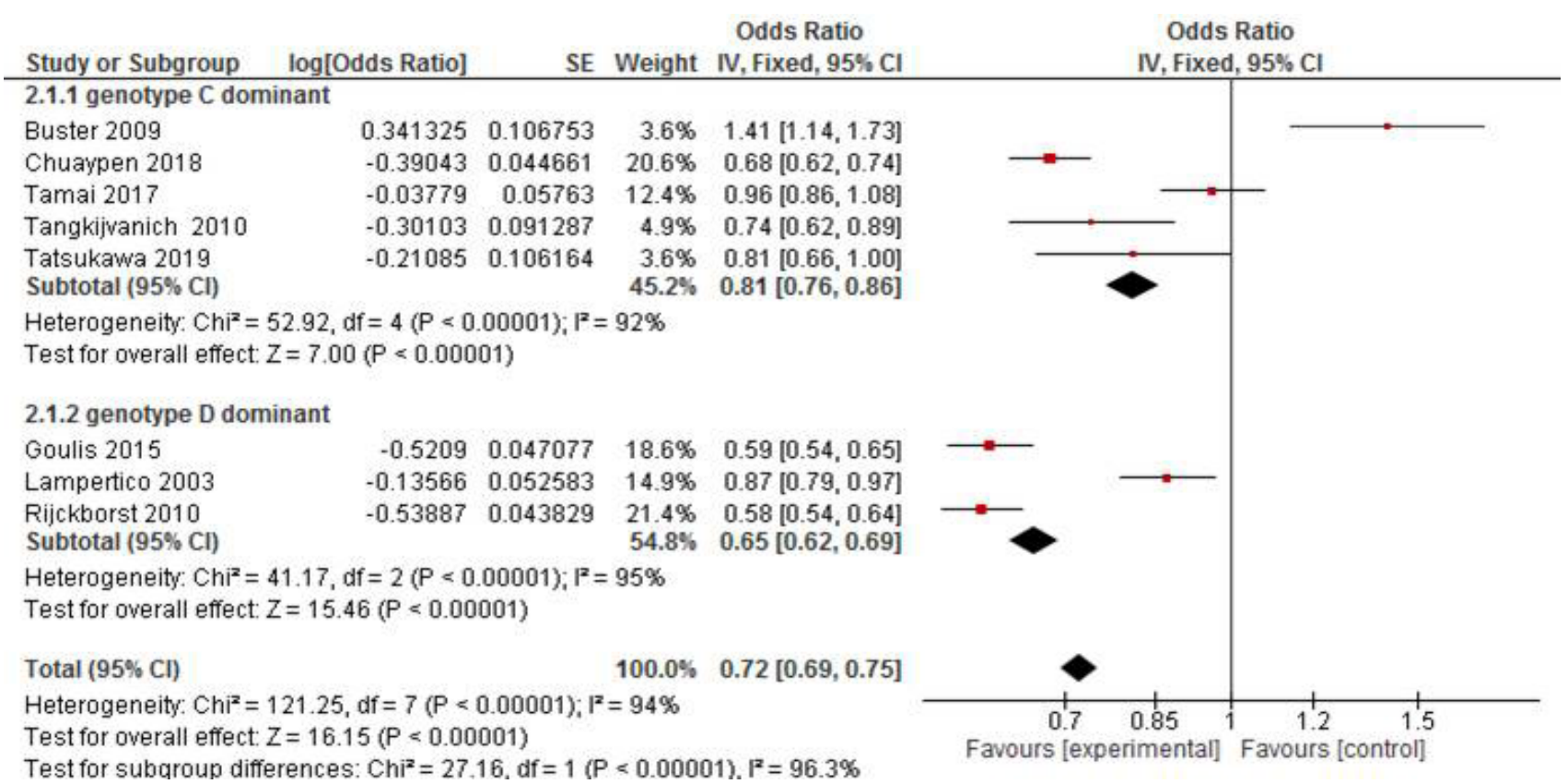

Fig. 4. Distribution of studies having genotype $\mathrm{C}$ or $\mathrm{D}$ dominant population based on the ratio of the number of responders to nonresponders. The $95 \%$ confidence interval for each study is plotted in horizontal lines around the baseline ratio. The rhombic mark is the result of a combination of studies with a $95 \%$ confidence interval.

\section{DISCUSSION}

The biological activity of PEG interferon is related to its interferon fraction. PEG Interferon-alpha 2A binds to the type 1 interferon receptor and dimerizes it. Receptor dimerization activates several intracellular signal transduction pathways, mainly through the JAK/STAT pathway(Sarasin-Filipowiczetal.,2009; Grace etal.,2005).

This process enhances the phagocytic activity of macrophages and cytotoxic activity of lymphocytes for target cells. The polyethylene glycol portion of the drug protects the drug molecule from proteolytic degradation, thereby extending its half-life and reducing the likelihood of an immune response by physically covering the protein portion of the drug and reducing access to it (Feld and Hoofnagle, 2005; Perry and Jarvis, 2001).

The efficacy of $40 \mathrm{kDa}$ of IGF-interferon was compared with conventional interferon in 194 patients. In that study, PEG interferon decreased HBV compared to conventional interferon in $\mathrm{HBeAg}$ negative chronic hepatitis treatment, by DNA and ALT naturalization. The overall conclusions drawn from the effects of the drug on HBV-DNA depletion, HBeAg negative, and liver enzymes normalization were $24 \%$ when used with peg-interferon and $12 \%$ with conventional interferon (Cooksley et al., 2003).

However our study evaluated the response to PEG interferon therapy and revealed that in 1655 subjects with negative Hbe Ag chronic hepatitis, response to treatment happens in a lesser number of patients. While there was high heterogeneity in our analysis, we separated studies based on the most frequent genotype. Results showed a better response in populations with $\mathrm{C}$ genotype. Ten genotypes (A-J) and several sub-genotypes have been reported for HBV DNA (Kao et al., 2000).

These genotypes are geographically and ethnically dispersed throughout the world, as Genotypes A (serotype adw) and D (serotype ayw) are predominant in Europe and the US, while Genotype B (serotype adw) and C (serotype adr) are widespread in China and Southeast Asia (Schaefer, 2007).

These genotypes cause different courses, the severity of clinical symptoms, response to treatment, resistance to medications like PEG interferon-alpha and resistance to HBe A seroconversion (Liaw et al., 2011; Reijnders et al., 2011).

Spontaneous $\mathrm{HBeAg}$ seroconversion is much higher in patients with genotype $B$ than in patients with genotype C. Virus genotype not only predicts clinical outcomes but also correlates with response to PEG interferon treatment. Genotype A is an independent risk factor for the progression of acute infection to chronic infection. Acute infection in Genotypes A and D patients may be more vulnerable to develop a chronic infection than Genotypes $\mathrm{B}$ and $\mathrm{C}$ patients. Spontaneous HBeAg seroconversion was 
less likely in genotypes $\mathrm{C}$ and $\mathrm{D}$ than in genotype $\mathrm{A}$ and B. Genotype $\mathrm{C}$ and D are most commonly associated with severe liver diseases including cirrhosis and hepatocellular carcinoma. The response to interferon treatment, especially in Genotypes A and B, is seen to be better than Genotypes $\mathrm{C}$ and $\mathrm{D}$. While our study made a comparison between $\mathrm{C}$ and $\mathrm{D}$ genotype dominant populations in response to PEG interferon and revealed better response in genotype $\mathrm{C}$ dominant populations. We defined subgroups based on the most frequent genotype seen in the population as most studies hadn't separated responders and non-responders based on each genotype.

\section{CONCLUSION AND RECOMMENDATION}

According to the results of the present study, it was shown that the proportion of responders to nonresponder individuals treated with PEG-Inf alone was less than one, meaning that those who responded to treatment were less than those who didn't. so PEG interferon may not be the best choice alone. However, in our study, there was heterogeneity. To investigate the source of heterogeneity, as there was no considerable difference in gender and age in included studies (most of the population was male between 30-50 years old), Genotypes and their effects were examined, which genotype $\mathrm{C}$ dominant studies had a better response than those with genotype $\mathrm{D}$, but this response was still insufficient.

\section{Statement of conflict of interest}

The authors declare no conflict of interest.

\section{REFERENCES}

Asrani, S.K., Devarbhavi, H., Eaton, J. and Kamath, P.S., 2019. Burden of liver diseases in the world. J. Hepatol., 70: 151-171. https://doi.org/10.1016/j. jhep.2018.09.014

Bonino, F., Marcellin, P., Lau, G.K., Hadziyannis, S., Jin, R., Piratvisuth, T., Germanidis, G., Yurdaydin, C., Diago, M., Gurel, S. and Lai, M.Y., 2007. Predicting response to peginterferon $\alpha-2 \mathrm{a}$, lamivudine and the two combined for $\mathrm{HBeAg}$ negative chronic hepatitis B. Gut, 56: 699-705. https://doi.org/10.1136/gut.2005.089722

Brook, M.G., Karayiannis, P. and Thomas, H.C., 1989. Which patients with chronic hepatitis $\mathrm{B}$ virus infection will respond to $\alpha$-interferon therapy? A statistical analysis of predictive factors. Hepatology, 10: 761-763. https://doi.org/10.1002/ hep. 1840100502

Buster, E.H., Hansen, B.E., Lau, G.K., Piratvisuth, T.,
Zeuzem, S., Steyerberg, E.W. and Janssen, H.L., 2009. Factors that predict response of patients with hepatitis B e antigen-Positive chronic hepatitis B to peginterferon-alfa. Gastroenterology, 137: 20022009. https://doi.org/10.1053/j.gastro.2009.08.061

Charre, C., Levrero, M., Zoulim, F. and Scholtès, C., 2019. Non-invasive biomarkers for chronic hepatitis B virus infection management. Antiviral Res., 169: 104553. https://doi.org/10.1016/j. antiviral.2019.104553

Chu, C.J., Hussain, M. and Lok, A.S.F., 2002. Quantitative serum HBV DNA levels during different stages of chronic hepatitis B infection. Hepatology, 36: 1408-1415. https://doi. org/10.1002/hep.1840360617

Chuaypen, N., Posuwan, N., Chittmittraprap, S., Hirankarn, N., Treeprasertsuk, S., Tanaka, Y., Shinkai, N., Poovorawan, Y. and Tangkijvanich, P., 2018. Predictive role of serum HBsAg and HBcrAg kinetics in patients with $\mathrm{HBeAg}$-negative chronic hepatitis B receiving pegylated interferon-based therapy. Clin. Microbiol. Infect., 24: 306. https:// doi.org/10.1016/j.cmi.2017.07.016

Cooksley, W.G., Piratvisuth, T., Lee, S.D., Mahachai, V., Chao, Y.C., Tanwandee, T., Chutaputti, A., Chang, W.Y., Zahm, F.E. and Pluck, N., 2003. Peginterferon a2b(40kDa): An advance in the treatment of hepatitis $\mathrm{Be} \mathrm{Ag}$ positive chronic hepatitis B. J. Hepatol., 10: 298-305. https://doi. org/10.1046/j.1365-2893.2003.00450.x

de Niet, A., Stelma, F., Jansen, L., Sinnige, M.J., Remmerswaal, E.B., Takkenberg, R.B., Kootstra, N.A., Reesink, H.W., van Lier, R.A. and van Leeuwen, E.M., 2016. Restoration of T cell function in chronic hepatitis B patients upon treatment with interferon based combination therapy. $J$. Hepatol., 64: 539-546. https://doi.org/10.1016/j. jhep.2015.10.013

Feld, J.J. and Hoofnagle, J.H., 2005. Mechanism of action of interferon and ribavirin in treatment of hepatitis C. Nature, 436: 967. https://doi. org/10.1038/nature04082

Fujisawa, T., Komatsu, H., Inui, A., Sogo, T., Miyagawa, Y., Fujitsuka, S., Sekine, I., Kosugi, T. and Inui, M., 2000. Long-term outcome of chronic hepatitis $\mathrm{B}$ in adolescents or young adults in follow-up from childhood. J. Pediatr. Gastroenterol. Nutr., 30: 201-206. https://doi.org/10.1097/00005176200002000-00019

Fung, J., Lai, C.L., Seto, W.K. and Yuen, M.F., 2016. Emerging drugs for the treatment of hepatitis B. Expert Opin. Emerg. Drugs, 21: 183-193. https:// 
doi.org/10.1517/14728214.2016.1162155

Goulis, I., Karatapanis, S., Akriviadis, E., Deutsch, M., Dalekos, G.N., Raptopoulou-Gigi, M., Mimidis, K., Germanidis, G., Drakoulis, C., Triantos, C. and Zintzaras, E., 2015. On-treatment prediction of sustained response to peginterferon alfa-2a for HB eAg-negative chronic hepatitis B patients. Liver Int., 35: 1540-1548. https://doi.org/10.1111/ liv. 12725

Grace, M.J., Lee, S., Bradshaw, S., Chapman, J., Spond, J., Cox, S., DeLorenzo, M., Brassard, D., Wylie, D., Cannon-Carlson, S. and Cullen, C., 2005. Site of pegylation and polyethylene glycol molecule size attenuate interferon- $\alpha$ antiviral and antiproliferative activities through the JAK/STAT signaling pathway. J. biol. Chem., 280: 6327-6336. https://doi.org/10.1074/jbc.M412134200

Hackshaw, A. (ed.), 2009. Statistical formulae for calculating some $95 \%$ confidence intervals. In: A concise guide to clinical trials. Wiley Online Library, pp. 205-207.

Kao, J.H., Chen, P.J., Lai, M.Y. and Chen, D.S., 2000. Hepatitis B genotypes correlate with clinical outcomes in patients with chronic hepatitis B. Gastroenterology, 118: 554-559. https://doi. org/10.1016/S0016-5085(00)70261-7

Lampertico, P., Del Ninno, E., Viganò, M., Romeo, R., Donato, M.F., Sablon, E., Morabito, A. and Colombo, M., 2003. Long-term suppression of hepatitis $\mathrm{B}$ e antigen-negative chronic hepatitis $\mathrm{B}$ by 24-month interferon therapy. Hepatology, 37: 756-763. https://doi.org/10.1053/jhep.2003.50148

Lee, W.M., 1997. Hepatitis B virus infection. New Engl. J. Med., 337: 1733-1745. https://doi.org/10.1056/ NEJM199712113372406

Liaw, Y.F., Jia, J.D., Chan, H.L., Han, K.H., Tanwandee, T., Chuang, W.L., Tan, D.M., Chen, X.Y., Gane, E., Piratvisuth, T. and Chen, L., 2011. Shorter durations and lower doses of peginterferon alfa-2a are associated with inferior hepatitis $B$ e antigen seroconversion rates in hepatitis B virus genotypes B or C. Hepatology, 54: 1591-1599. https://doi. org/10.1002/hep. 24555

Mahoney, F.J., 1999. Update on diagnosis, management, and prevention of hepatitis B virus infection. Clin. Microbiol. Rev., 12: 351-366. https://doi. org/10.1128/CMR.12.2.351

Malani, P.N., 2010. Mandell, Douglas, and Bennett's principles and practice of infectious diseases. $J$. Am. med. Assoc., 304: 2067-2071. https://doi. org/10.1001/jama.2010.1643

Manesis, E.K. and Hadziyannis, S.J., 2001. Interferon $\alpha$ treatment and retreatment of hepatitis B e antigennegative chronic hepatitis B. Gastroenterology, 121: 101-109. https://doi.org/10.1053/gast.2001.25524

Mohanty, S.R., Kupfer, S.S. and Khiani, V., 2006. Treatment of chronic hepatitis B. Nat. Clin. Pract. Gastroenterol. Hepatol., 3: 446-458. https://doi. org/10.1038/ncpgasthep0550

Moucari, R., Mackiewicz, V., Lada, O., Ripault, M.P., Castelnau, C., Martinot-Peignoux, M., Dauvergne, A., Asselah, T., Boyer, N., Bedossa, P. and Valla, D., 2009. Early serum HBsAg drop: a strong predictor of sustained virological response to pegylated interferon alfa- $2 \mathrm{a}$ in $\mathrm{HBeAg-negative}$ patients. Hepatology, 49: 1151-1157. https://doi. org/10.1002/hep. 22744

Nicolini, L.A., Orsi, A., Tatarelli, P., Viscoli, C., Icardi, G. and Sticchi, L., 2019. A global view to HBV chronic infection: Evolving strategies for diagnosis, treatment and prevention in immunocompetent individuals. Int. J. environ. Res. Publ., 16: 3307. https://doi.org/10.3390/ijerph16183307

Perry, C.M. and Jarvis, B., 2001. Peginterferon- $\alpha-$ 2a (40kD). Drugs, 61: 2263-2288. https://doi. org/10.2165/00003495-200161150-00013

Raimondo, G. and Pollicino, T., 2016. Occult HBV infection. In: Hepatitis $B$ virus in human diseases (eds. Y.F. Liaw and F. Zoulim). Springer International Publishing, Switzerland, pp. 277-301. https://doi.org/10.1007/978-3-319-22330-8_13

Reijnders, J.G., Rijckborst, V., Sonneveld, M.J., Scherbeijn, S.M., Boucher, C.A., Hansen, B.E. and Janssen, H.L., 2011. Kinetics of hepatitis B surface antigen differ between treatment with peginterferon and entecavir. J. Hepatol., 54: 449-454. https://doi. org/10.1016/j.jhep.2010.07.046

Rijckborst, V., Hansen, B.E., Cakaloglu, Y., Ferenci, P., Tabak, F., Akdogan, M., Simon, K., Akarca, U.S., Flisiak, R., Verhey, E. and van Vuuren, A.J., 2010. Early on-treatment prediction of response to peginterferon alfa-2a for $\mathrm{HBeAg}$-negative chronic hepatitis B using HBsAg and HBV DNA levels. Hepatology, 52: 454-461. https://doi.org/10.1002/ hep. 23722

Sarasin-Filipowicz, M., Wang, X., Yan, M., Duong, F.H., Poli, V., Hilton, D.J., Zhang, D.E. and Heim, M.H., 2009. Alpha interferon induces long-lasting refractoriness of JAK-STAT signaling in the mouse liver through induction of USP18/UBP43. Mol. Cell. Biol., 29: 4841-4851. https://doi.org/10.1128/ MCB.00224-09

Schaefer, S., 2007. Hepatitis B virus taxonomy and hepatitis B virus genotypes. World J. Gastroenterol., 
13: 14. https://doi.org/10.3748/wjg.v13.i1.14

Sundaram, V. and Kowdley, K., 2015. Management of chronic hepatitis B infection. Br. med. J., 351: 4263. https://doi.org/10.1136/bmj.h4263

Tamai, H., Ida, Y., Shingaki, N., Shimizu, R., Fukatsu, K., Itonaga, M., Yoshida, T., Maeda, Y., Moribata, K., Maekita, T. and Iguchi, M., 2017. Add-on pegylated interferon Alpha-2a therapy in chronic hepatitis B Japanese patients treated with entecavir. Hepat. Res. Treat., 2017: 2093847. https://doi. org/10.1155/2017/2093847

Tangkijvanich, P., Komolmit, P., Mahachai, V., Sanguanmoo, P., Theamboonlers, A. and Poovorawan, Y., 2010. Comparison between quantitative hepatitis B surface antigen, hepatitis B e-antigen and hepatitis B virus DNA levels for predicting virological to pegylated interferon-alpha- $2 b$ therapy in hepatitis B e-antigen-positive chronic hepatitis B. Hepatol. Res., 40: 269-277. https://doi. org/10.1111/j.1872-034X.2009.00592.x

Tatsukawa, Y., Tsuge, M., Kawakami, Y., Hiyama, Y., Murakami, E., Kurihara, M., Nomura, M., Tsushima, K., Uchida, T., Nakahara, T. and Miki, D., 2018. Reduction of hepatitis B surface antigen in sequential versus add-on pegylated interferon to nucleoside/nucleotide analogue therapy in $\mathrm{HBe}-$ antigen-negative chronic hepatitis $\mathrm{B}$ patients: A pilot study. Antivir. Therp., 23: 639-646. https://doi. org/10.3851/IMP3240

Thomas, D.L., 2019. Global elimination of chronic hepatitis. New Engl. J. Med., 380: 2041-2050. https://doi.org/10.1056/NEJMra1810477

Wilkins, T., Sams, R. and Carpenter, M., 2019. Hepatitis B: Screening, prevention, diagnosis, and treatment. Am. Family Physician, 99: 314-323.

Yuen, M.F., Seto, W.K., Fung, J., Wong, D.K., Yuen, J.C. and Lai, C.L., 2011. Three years of continuous entecavir therapy in treatment-naive chronic hepatitis B patients: Viral suppression, viral resistance, and clinical safety. Am. J. Gastroenterol., 106: 1264-1271. https://doi. org/10.1038/ajg.2011.45

Zeng, G., Wang, Z., Wen, S., Jiang, J., Wang, L., Cheng, J., Tan, D., Xiao, F., Ma, S., Li, W. and Luo, K., 2005. Geographic distribution, virologic and clinical characteristics of hepatitis B virus genotypes in China. J. Viral Hepatitis, 12: 609-617. https://doi.org/10.1111/j.1365-2893.2005.00657.x

Zhang, T., Zhang, Z., Zhang, Y., Ye, J. and Li, X., 2016. A lower PBMC estrogen receptor $\alpha$ gene expression in chronic hepatitis B is associated with a sustained virological response to pegylated interferon. $J$. Interferon Cytokine Res., 36: 120-128. https://doi. org/10.1089/jir.2014.0223 